\title{
Effect of Glass and Plastic Covers on the Performance of Solar Photovoltaic Cells in the Presence of Mud
}

\author{
Abdelnabi Ali Elamin and Samah Osman Khairy Ahmed. \\ Department of physics, Faculty of Science and Technology, Omdurman Islamic University, Omdurman, Sudan.
}

Email address:

aealamain2016@oiu.edu.sd (A. A. Elamin)

\section{*Corresponding author}

To cite this article:

Abdelnabi Ali and, Samah Osman Khairy Ahmed, Effect of Glass and Plastic Covers on the Performance of Solar Photovoltaic Cells in the Presence of Mud, , Omdurman Islamic University Journal, Vol. 18, No. 1, 2022, pp. 30-40, https://doi.org/ 10.52981/oiuj.v18i1.1884.

Received: 05, 12, 2021; Accepted: 1, 16, 2022; Published19, 1, 2021.

\begin{abstract}
:
With climate change resulting from the use of fossil fuel sources and the increasing use of energy, the sources of renewable energy is growing interest in, which includes direct use of the radiation from the sun through photo-voltaic cells. Photovoltaic solar cell covers in Sudan are exposed during the year to many environmental factors such as rainfall and dust accumulation in summer, autumn and winter, which weaken the performance of solar cells, as well as the shades of trees and tall buildings which affect the efficiency of these cells in the morning and afternoon. This paper aims to evaluate the effect of mud on the performance when one use glass and plastic covers for solar photovoltaic cells . Four different covers were installed on the photovoltaic solar cells, namely polycarbonate (PC), polymethylmethacrylate (PMMA), solar glass and ordinary glass for a study to assess their quality for resistance to mud. Experimental work shows that the drop rate of the maximum power and the drop rate of efficiency are $47 \%, 60 \%$, 49\%, and $46 \%$ for PC cover, PMMA cover, solar glass cover, and classic glass cover respectively. Thus it is not recommended to use PMMA coating as mud insulation for solar photovoltaic cells.
\end{abstract}

Keywords: Glass, Plastic, Covers, Solar Photovoltaic Cells, Mud 


\section{Introduction}

Renewable energy is energy which is generated from natural sources and can be generated again and again as and when required. i.e. sun wind, rain, tides. Worldwide, oil prices will then rise considerably favoring the introduction of various renewable energy sources such as the direct conversion of solar energy (solar cells) ,but also other slake for example, hydroelectric- and wind-power systems. Renewable energy source neither run out nor have any signify can harmful effects on our environment [1,2]. The economic development and growth by generating the Energy. With the rapid growth of development and the drive to expand the economy, society demands more electricity. Coupled with the realization that unsustainable energy production can have a detrimental effect on our environment $[3,4,5]$. Solar energy is the most prolific method of energy capture in nature. The economic drive to make solar cells more cost effective and efficient has driven developments in many different deposition technologies, including dipping, plating, thick film deposition and thin film deposition [6, 7].

Typically, in order for solar energy to work efficiently and supply energy to a building, a very large amount of space is required, in the form of rooftops or land, in order to install solar panels; these solar panel space requirements are a large impediment to practical usage. This drawback drove researchers to come up with transparent solar cells (TSCs), which solve the problem by turning any sheet of glass into a photovoltaic solar cell.

The previous study shows much the degradation of efficiency for PV solar cell through factors including location, environment, and weather conditions [8-17]. The environment, and weather conditions include rain, cloud, shading from structures such as trees and buildings, dust accumulating on panels, seasonal changes, meteoro-logical impact as snow, and migration routes of animals (birds, etc.) near the production site $[18,19]$. The contamination of panels caused by these factors affects the out-put voltage of the panel and therefore the energy generation [20].

This motivates to evaluate the performance for four different covefor which were installed on the photovoltaic solar cells, namely polycarbonate (PC), polymethylmethacrylate (PMMA), solar glass and ordinary glass for a study to assess their quality for resistance to mud. Experimental works concerning these procedures are exhibited in section 2. Section 3 is concerned with findings and discussion while Section 4 and 5 are devoted to the conclusion recommendation respectively.

\section{Experimental works}

The experiment was conducted on solar cells to study the effect of transparent plastic sheets on the efficiency of the solar cell in the presence of mud. The readings were taken several times and efficiency was calculated. This section contains tools and tools used for testing and how to work.

\subsection{Experiment Apparatus and Setup}

The electrical specifications of the panels used in this study were as follows:

1- Solar cells in sizes $(18 \times 9 \mathrm{~cm})$, different surface covers polycarbonate(PC), Polymethyl methacrylate(PMMA), solar glass, plain glass) which was described the physical properties in table 1.

2- 2 Multimeter.

3- Resistant.

4- Light sourcep $=50 \mathrm{w}$.

5- Connecting wires. 


\subsection{Cover Polymers Surface of PV Solar Cell}

Scientists have classified polymers as one of the important classes of materials. They include rubber, plastics, and resins, and in this work, the polymer is used as a cover for solar cells such as:

\subsubsection{Polycarbonate (PC)}

The unpacked polycarbonate showed in Table (1) is a tough, transparent engineering thermoplastic material that offers extremely high impact strength and a high modulus of elasticity. It also has high temperature deflection heat and very little moisture absorption. These properties, along with the good insulating properties of low frequency and high voltage, make polycarbonate a primary material for electrical and electronic components. Its strength, impact resistance, and transparency (unfilled grades only) also make it an ideal material for some transparent structural applications.

\subsubsection{Properties of Polycarbonate (Pc)}

Polymer is derived from the Greek words, poly = many and mers = parts or units with a high molecular mass, each molecule consists of a very large number of single structural units that are joined together in a regular fashion. In other words polymers are giant molecules with a high molecular weight, called large molecules, which accumulate by binding a large number of small molecules called monomers. Polymerizations resulting from the reaction of monomers combine to form a polymer [21]. Polymerization is a chemical reaction in which two or more substances combine together or without anything like water, heat, or any other solvent that develops to form a A high molecular weight molecule. The product is called a polymer and the starting material is called monomer. The physical properties of polycarbonate (PC) as shown in Table No. (1).

Table 1 TYPICAL PROPERTIES Of Polycarbonate (PC)[21]

\begin{tabular}{|c|c|c|}
\hline Property & Unfilled & 30\% Glass \\
\hline \multicolumn{3}{|l|}{ PHYSICAL } \\
\hline \multirow[t]{2}{*}{ Density $\left(\mathrm{lb} / \mathrm{in}^{3}\right)\left(\mathrm{g} / \mathrm{cm}^{3}\right)$} & 0.043 & 0.052 \\
\hline & 1.2 & 1.43 \\
\hline Water Absorption, 24 hrs (\%) & 0.12 & 0.12 \\
\hline \multicolumn{3}{|l|}{ MECHANICAL } \\
\hline Tensile Strength (psi) & 9,500 & 19,000 \\
\hline Tensile Modulus (psi) & 320,000 & - \\
\hline Tensile Elongation at Break (\%) & 60 & 10 \\
\hline Flexural Strength (psi) & 15,000 & 23,000 \\
\hline Flexural Modulus (psi) & 375,000 & $1,100,000$ \\
\hline Compressive Strength (psi) & 12,000 & 18,000 \\
\hline Compressive Modulus (psi) & 240,000 & 500,000 \\
\hline Hardness, Rockwell & $\begin{array}{l}\text { M70 } \\
\text { R118 }\end{array}$ & M92 \\
\hline IZOD Notched Impact (ft-lb/in) & 13 & 2 \\
\hline Tensile Modulus (psi) & 320,000 & - \\
\hline Tensile Elongation at Break (\%) & 60 & 10 \\
\hline Flexural Strength (psi) & 15,000 & 23,000 \\
\hline Flexural Modulus (psi) & 375,000 & $1,100,000$ \\
\hline
\end{tabular}



Photovoltaic Cells in the Presence of Mud

\begin{tabular}{|c|c|c|}
\hline Hardness, Rockwell & $\begin{array}{l}\text { M70 / } \\
\text { R118 }\end{array}$ & M92 \\
\hline IZOD Notched Impact (ft-lb/in) & 13 & 2 \\
\hline \multicolumn{3}{|l|}{ THERMAL } \\
\hline $\begin{array}{l}\text { Coefficient of Linear Thermal Expansion } \\
\left(\text { x } 10-5 \text { in./in. } /{ }^{\circ} \mathrm{F}\right)\end{array}$ & 3.9 & 1.2 \\
\hline $\begin{array}{l}\text { Heat Deflection Temp }\left({ }^{\circ} \mathrm{F} /{ }^{\circ} \mathrm{C}\right) \\
\text { at } 264 \mathrm{psi}\end{array}$ & $\begin{array}{l}270 \quad / \\
132\end{array}$ & $295 / 146$ \\
\hline Glass Transition Temp $\left({ }^{\circ} \mathrm{F} /{ }^{\circ} \mathrm{C}\right)$ & $\begin{array}{ll}293 \\
145\end{array}$ & $300 / 149$ \\
\hline Max Operating Temp $\left({ }^{\circ} \mathrm{F} /{ }^{\circ} \mathrm{C}\right)$ & $\begin{array}{l}250 \\
121\end{array}$ & $270 / 132$ \\
\hline $\begin{array}{l}\text { Thermal Conductivity } \\
\left(\mathrm{BTU}-\mathrm{in} / \mathrm{ft}^{2}-\mathrm{hr}^{\circ}{ }^{\circ} \mathrm{F}\right) \\
\left(\mathrm{x} 10-4 \mathrm{cal} / \mathrm{cm}-\mathrm{sec}-{ }^{\circ} \mathrm{C}\right)\end{array}$ & $\begin{array}{l}1.3 \\
6.9\end{array}$ & $\begin{array}{l}1.3 \\
6.9\end{array}$ \\
\hline $\begin{array}{l}\text { Flammability Rating } \\
\text { @ less than .45" (11.5mm) thickness } \\
@ .45 "(11.5 \mathrm{~mm}) \text { thickness and above }\end{array}$ & H-B V-0 & H-B V-0 \\
\hline \multicolumn{3}{|l|}{ ELECTRICAL } \\
\hline $\begin{array}{l}\text { Dielectric Strength (V/mil) short time, } \\
1 / 8 " \text { thick }\end{array}$ & 390 & 470 \\
\hline Dielectric Constant at $60 \mathrm{~Hz}$ & 3.17 & 3.35 \\
\hline Dissipation Factor at $60 \mathrm{~Hz}$ & 0.0009 & 0.0011 \\
\hline Volume Resistivity (ohm-cm)at 50\% RH & 1016 & 1016 \\
\hline
\end{tabular}

\subsubsection{Acrylic (PMMA)}

Acrylics (Polymathic -Methacrylate or PMMA) is an amorphous thermoplastic which is optically transparent, unaffected by moisture, and offers a high strength-to-weight ratio. Common trade names of acrylic include Plexiglas, Lucite, and the physical properties of Acrylics as shown in table (2). 
Table 2. TYPICAL PROPERTIES Of ACRYLIC PMMA[21]

\begin{tabular}{|c|c|}
\hline Property & Acrylic \\
\hline \multicolumn{2}{|l|}{ PHYSICAL } \\
\hline $\begin{array}{l}\text { Density }\left(\mathrm{lb} / \mathrm{in}^{3}\right) \\
\left(\mathrm{g} / \mathrm{cm}^{3}\right)\end{array}$ & $\begin{array}{l}\text { Density }\left(\mathrm{lb} / \mathrm{in}^{3}\right) \\
\left(\mathrm{g} / \mathrm{cm}^{3}\right)\end{array}$ \\
\hline WaterAbsorption, $24 \mathrm{hrs}(\%)$ & WaterAbsorption, 24hrs(\%) \\
\hline \multicolumn{2}{|l|}{ MECHANICAL } \\
\hline Tensile Strength(psi) & $8,000-11,000$ \\
\hline Tensile Modulus(psi) & $350,000-500,000$ \\
\hline Tensile Elongation at Break $(\%)$ & 2 \\
\hline Flexural Strength(psi) & $12,000-17,000$ \\
\hline Flexural Modulus(psi) & $350,000-500,000$ \\
\hline Compressive Strength(psi) & $11,000-19,000$ \\
\hline Compressive Modulus(psi) & - \\
\hline Hardness, & M80-M100 \\
\hline IZOD Notched Impact(ft-lb/in) & 0.3 \\
\hline \multicolumn{2}{|l|}{ Thermal properties } \\
\hline $\begin{array}{l}\text { Coefficient of Linear Thermal Expansion } \\
\left(\mathrm{x} 10-5 \mathrm{in} . / \mathrm{in} .{ }^{\circ} \mathrm{F}\right)\end{array}$ & $5-9$ \\
\hline Heat Deflection Temp $\left({ }^{\circ} \mathrm{F} /{ }^{\circ} \mathrm{C}\right)$ at $264 \mathrm{psi}$ & $150-210 / 65-100$ \\
\hline Melting Temp $\left({ }^{\circ} \mathrm{F} /{ }^{\circ} \mathrm{C}\right)$ & $265-285 / 130-140$ \\
\hline Max Operating Temp $\left({ }^{\circ} \mathrm{F} /{ }^{\circ} \mathrm{C}\right)$ & $150-200 / 65-93$ \\
\hline $\begin{array}{l}\text { Thermal Conductivity } \\
\left(\mathrm{BTU}-\mathrm{in} / \mathrm{ft}^{2}-\mathrm{hr}-{ }^{\circ} \mathrm{F}\right) \\
\left(\mathrm{x} 10-4 \mathrm{cal} / \mathrm{cm}-\mathrm{sec}-{ }^{\circ} \mathrm{C}\right)\end{array}$ & $\begin{array}{l}3.9 \\
1.2\end{array}$ \\
\hline Flammability Rating & - \\
\hline
\end{tabular}

\begin{tabular}{|l|l|}
\hline Property & Acrylic \\
\hline ELECTRICAL & 400 \\
\hline Dielectric Strength(V/mil)shorttime,1/8"thick & 4.0 \\
\hline Dielectric Constant at $60 \mathrm{~Hz}$ & 0.05 \\
\hline DissipationFactorat60 Hz & 92 \\
\hline OPTICAL & $1.48-1.50$ \\
\hline Light Transmission ,minimum(\%) & \\
\hline Refractive &
\end{tabular}




\subsection{The Method of Work}

Four different covers were installed on the photovoltaic solar cells in Energy Researches Center, Soba, Sudan, namely polycarbonate (PC), polymethylmethacrylate (PMMA), solar glass and ordinary glass. The four different solar cell were exposed to mud and presented to the optical source at 45 angle and was connected to the two metering meters and the two metering devices, one to measure the voltage difference $(\mathrm{v})$ in parallel and the other to measure the electrical current (I) respectively, and the voltage value was zero when the current is $\mathrm{V}$ and the current when the resistance is zero (I), and changed the value of the resistance each time and recorded the readings of the difference of voltage and current until the current read the zero and voltages to the maximum value and then draw the voltage and current curve and calculated efficiency and filler equations, repeated the same steps in the case of dust and clay and partial shadow on the cell and calculated Characteristics of Cells are both on their own.

\section{Results and Discussion}

In this section, the effect of solar cell covers such as ordinary glass cover, PC, PMMA and solar glass on the performance of solar photovoltaic cells, and the resistance of these covers to mud on the performance of solar cells are discussed.

From Fig. 1 to Fig. 4 it can be seen that the open-circuit voltage $\left(\mathrm{V}_{0 \mathrm{~V}}\right)$ and the short circuit current $\left(\mathrm{I}_{\mathrm{SC}}\right)$ decrease for all the covers of the solar cells exposed to the mud.

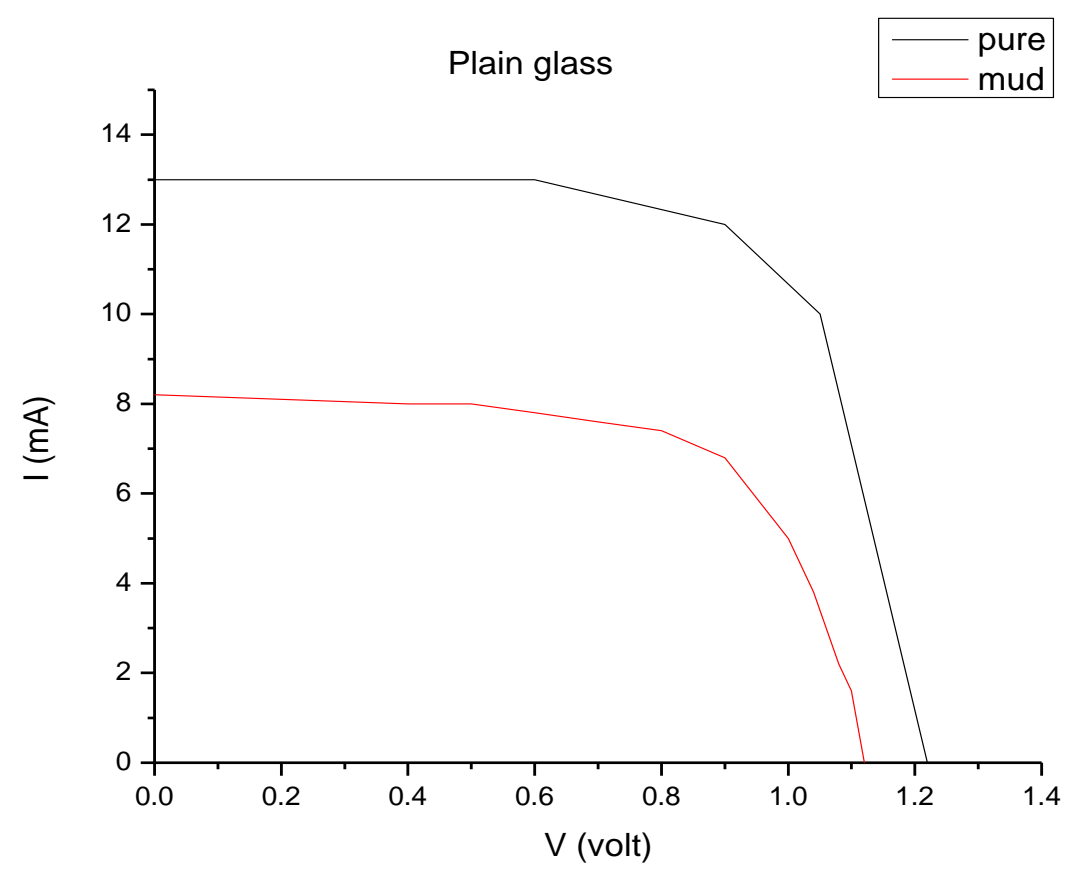

Figure 1: A. I-V characteristics for plain glass Cover 


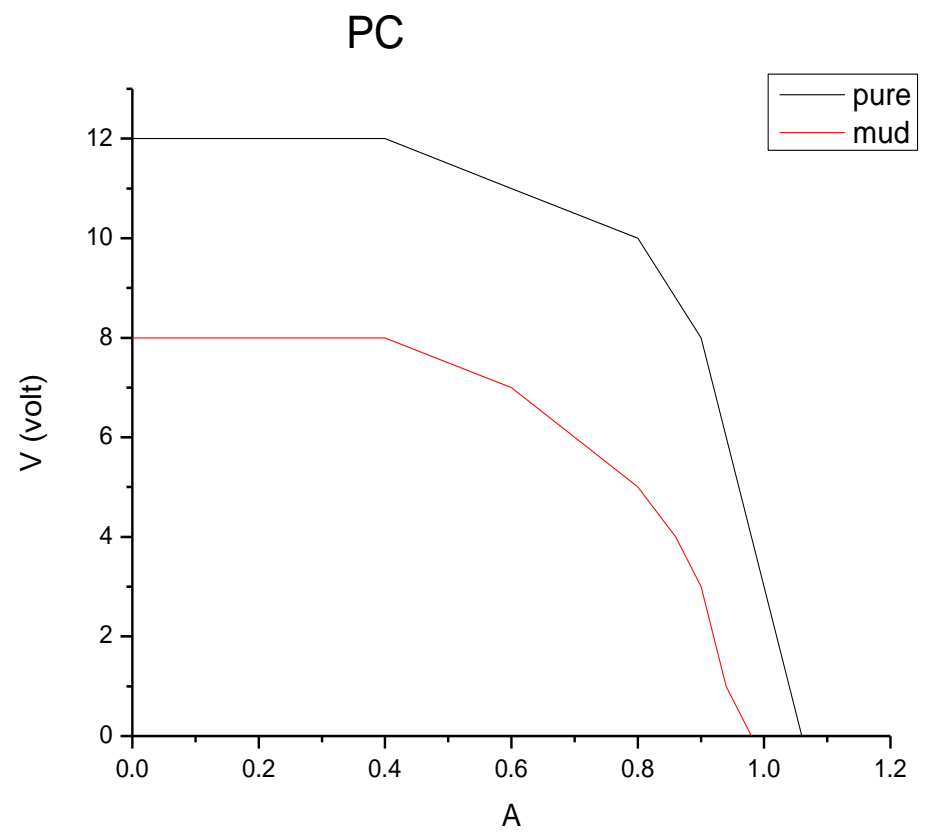

Figure 2: A. I-V characteristics for pure and mud PC

The main reason for the attenuation of low open-circuit voltage $\left(\mathrm{V}_{\mathrm{OV}}\right)$ and short circuit current $\left(\mathrm{I}_{\mathrm{SC}}\right)$ is the attenuation of light transmittance due to mud build-up on the solar PV cover. And because the process of mud accumulation is very easy, it starts first with rain and then accumulates a simple layer of dust until it covers the entire surface, then a second layer is deposited on top of it, and so on $[22,23]$.

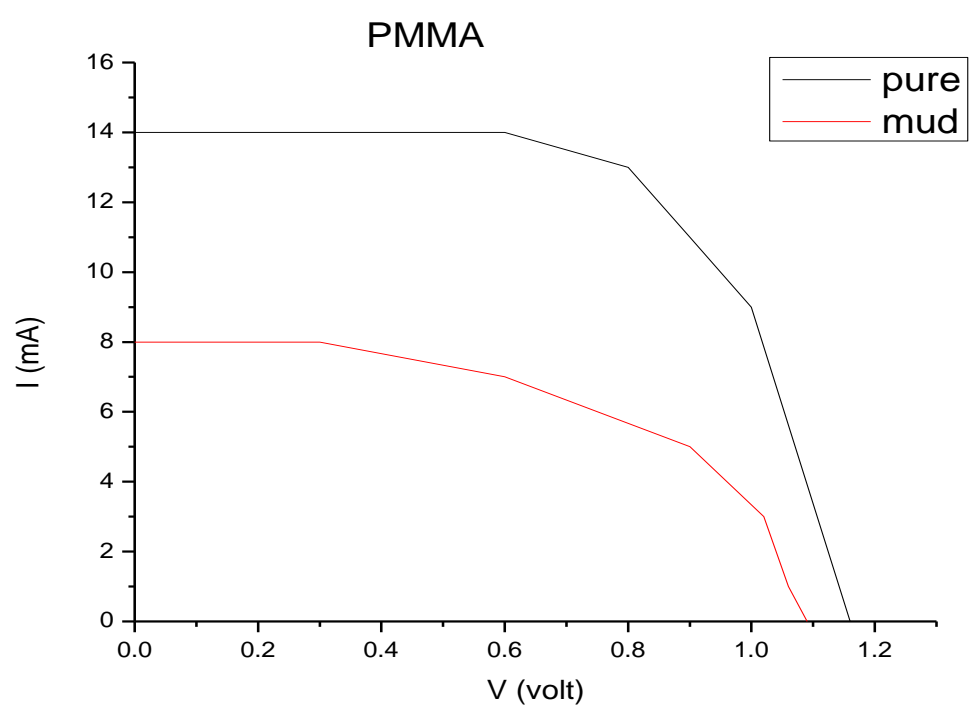

Figure 3: A. I-V characteristics for pure and mud PMMA 


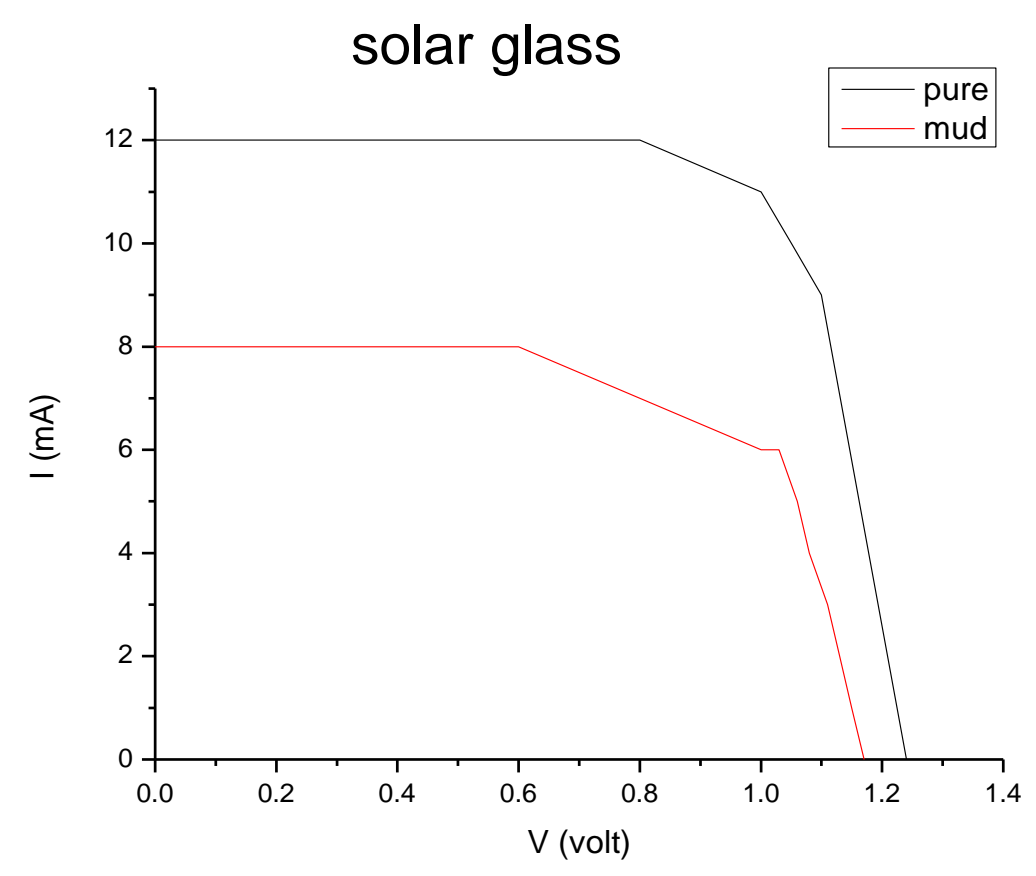

Figure 4: A. I-V characteristics for pure and mud solar glass

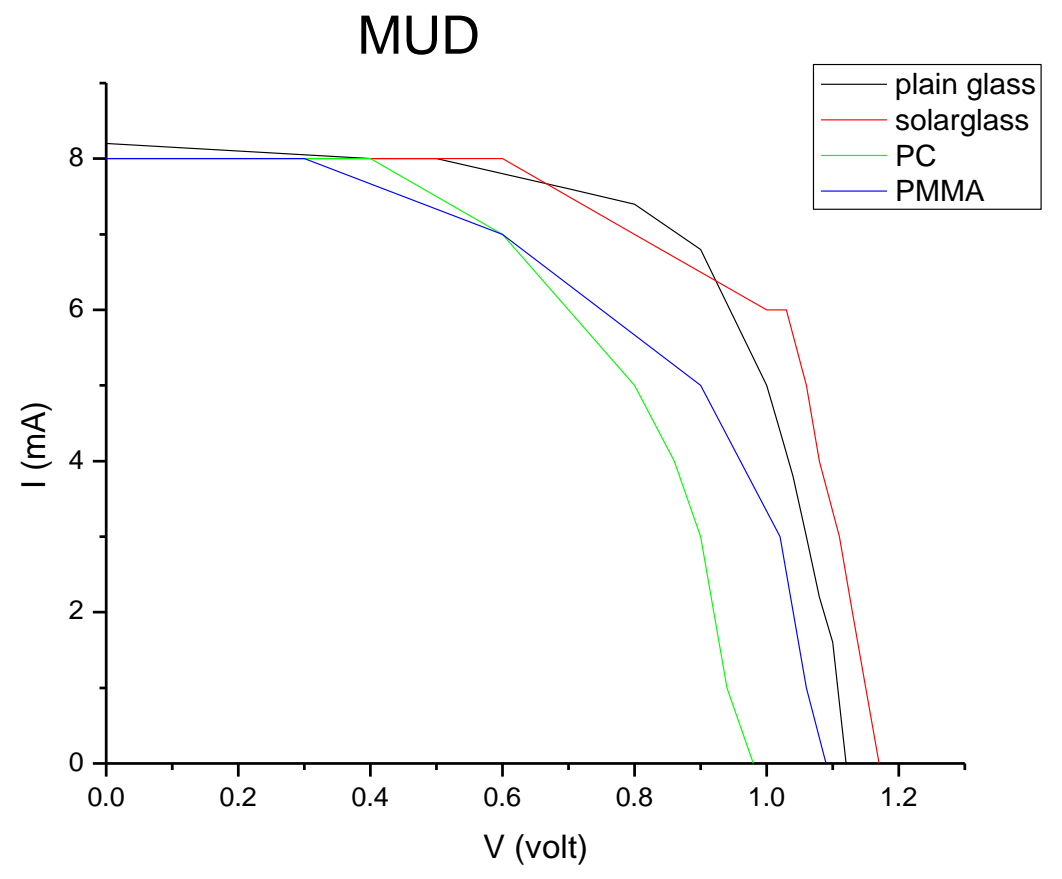

Figure 5: A. I-V characteristics for all solar cell layer mud layer

Various parameters such as maximum power, filling factor and efficiency of different surface photovoltaic cells can respond differently to slurries as shown in Table 6 to Table 7, Fig. 6, 7 and Fig. 5 respectively. 
Table 6. The maximum power drop rate for all covers solar cell samples with Mud layer

\begin{tabular}{|l|l|l|l|l|}
\hline Cover Sample & PC & PMMA & $\begin{array}{l}\text { Solar } \\
\text { glass }\end{array}$ & $\begin{array}{l}\text { Classic } \\
\text { glass }\end{array}$ \\
\hline Pure & 7.96 & 10.40 & 10.97 & 10.80 \\
\hline Mud & 4.21 & 4.20 & 5.57 & 5.92 \\
\hline $\begin{array}{l}\text { The maximum } \\
\text { power drop rate }\end{array}$ & $47 \%$ & $60 \%$ & $49 \%$ & $46 \%$ \\
\hline
\end{tabular}

Table 7. The Fill Factor drop rate for all cover solar cells samples with Mud layer

\begin{tabular}{|l|l|l|l|lc|}
\hline $\begin{array}{l}\text { Cover } \\
\text { Sample }\end{array}$ & PC & PMMA & Solar glass & Classic glass \\
\hline Pure & 0.623 & 0.641 & 0.723 & 0.678 & \\
\hline Mud Factor & 0.535 & 0.482 & 0.059 & 0.640 & \\
\hline $\begin{array}{l}\text { Fill } \\
\text { drop rate }\end{array}$ & $14 \%$ & $25 \%$ & $\mathbf{9 2 \%}$ & & \\
\hline
\end{tabular}

Table 8. The Efficiency drop rate for all cover solar cell samples with Mud layer

\begin{tabular}{|l|l|l|l|l|}
\hline Cover Sample & PC & PMMA & Solar glass & Classic glass \\
\hline Pure & 0.796 & 1.040 & 1.097 & 1.080 \\
\hline Mud & 0.421 & 0.419 & 0.557 & 0.587 \\
\hline $\begin{array}{l}\text { Efficiency } \\
\text { drop rate }\end{array}$ & $47 \%$ & $60 \%$ & $49 \%$ & $46 \%$ \\
\hline
\end{tabular}

From table 6 and table 8 it clears that the maximum power and the efficiency drop rate are $47 \%$, $60 \%, 49 \%$, and $46 \%$ for PC cover, PMMA cover, solar glass cover, and classic glass cover respectively. It is not recommended to use PMMA coating as mud insulation for solar photovoltaic cells.

\section{Conclusion}

At the end of the research in which the efficiency of solar cells was studied with different types of fiber covers, it was found that the solar cell cover made of polycarbonate resists the shading that occurs due to climate changes from dust, shade and mud if this cover is compared to other covers such as solar glass, plain glass and polymethyl meth acrylates. Hence, the cell efficiency is high when polycarbonate covering is used.

\section{Recommendations}

The recommendation required to conduct a lot of research related to solar cells because of their importance in our time to take advantage of clean energies (solar energy) by using other methods of modification in the components of solar cells to increase the efficiency of the cell and increase energy to obtain a greater benifit. One recommend the use of a polycarbonate cover with a rough surface to know the effect of the surface on the efficiency of the solar cell. One also needs the use of colored covers and studying the effect of colors on the efficiency of the solar cell. 


\section{References}

[1]. R.Swami , (2012), Solar cell ,International journal of scientic and research publications , volume 2 , page (1-5).

[2]. A.Mohmmad Bagher, M. Mohmmad Abdi vahid and M.Mohsen , (2015), Type of solar cell and Application, American journal of optics and photonics , page (95-113).

[3]. R. Kannan, K. C. Leong, R. Osman, H. K. Ho, and C. P. Tso, "Life cycle assessment study of solar PV systems: An example of a $2.7 \mathrm{kWp}$ distributed solar PV system in Singapore," Solar Energy, vol. 80, pp. 555-563, 2006.

[4]. A.Mohmmmad ,M.D.Abdalla ,R.Abdelgani , A.Mohmmad Elhussien and A.Alfaki ,(),Using Gum Arabic in Making solar cell by thine films Instead of polymers ,Journal of Applied physics (IOSR-JAP), Volume 8 ,page (26-32).

[5]. D.Celikler , (2013) ,Awareness about renewable energy of pre service science teachers in turkey, renewable energy, volume 60, page (343-348).

[6]. E.Kacan, (2015), Renewable energy awareness in vocational and technical education, volume 76 , page (126-134).

[7]. S.Davidsson , L.Grandell ,H.Wachtmeister and M.Hook .(2014) , Growth curves and sustained commissioning modelling of renewable energy :Investigating resource constraints for wind energy , Energy policy, volume 73 , page (767- 776) .

[8]. A.Ibrahim, (2011), Effect of Shadow and Dust on the performance of silicon solar cell, text Road publication, page (221-230).

[9]. S.Sulaiman, H.Hussain, N.siti, N.leh and M.Razali,(2011),Effects of Dust on the performance of PV panels, International journal of Mechanical, Mechatronic and Manufacturing Engineering, Volume 5, page (2028-2033).

[10]. A.Omer Mohmmad and A.Hasan, (2012), Effect of Dust Accumulation of Performance of photovoltaic Solar Module in sahara Environment, Journal of Basic and Applied Scientific Research, page (11030-11036).

[11]. E.Talib Hashim, (2013), Effect of dust and shadow on the efficiency of photovoltaic solar module at Baghdad climate condions , Iragi Journal of mechanical and material engineering, volume 13 , page (769-783).

[12]. E.Talib Hashim and T.Abd Hussien, (2016), Dust Effect on the efficiency of silicon mono crystalline solar modules at different tilt angles at Al -Jadryia climate conditions, Journal of Engineering, volume 22, page (56-73).

[13]. E.Talib Hashim and A.Gamal Khaled, (2016), Experimental and simulation for the effect of partial shading on solar panel performance, Journal of Engineering, volume 22 , page (87-99). 
[14]. F.Mohd Zaihidec ,S.Mekhilef ,M.Seyed mahoudian and B.Horan ,2016) ,Dustas an unalterable deteriorative affecting PV panels efficiency, Renewable and sustainable energy reviews, volume 65 ,page (1267-1278).

[15] . S.Baghzouz, (2008), On the impact of partial shading on pv output power, volume 16.

[16]. Mekhilef, S.; Saidur, R.; Kamalisarvestani, M., ( 2012), Effect of dust, humidity and air velocity on efficiency of photovoltaic cells. Renew. Sustain. Energy Rev, 16, 2920-2925. 3.

[17]. Casanova, J.Z.; Piliougine, M.; Carretero, J.; Bernaola, P.; Carpena, P.; Mora. Lopez, L.; Sidrach-Cardona, M.( 2011), Analysis of dust losses in photovoltaic modules. World Renew. Energy Congr., 2985-2992, doi:10.3384/ecp110572985.

[18]. Adıgüzel, E. (2018), Effect of Dust Particles in Different Sizes on the Efficiency of the Photovoltaic Panels. MSc Thesis, University of Istanbul, Istanbul, Turkey.

[19]. L.Dorobantu , M.O.Popescu, CL.Popesu and A.Craciunescu ,The effect of surface impurities on photovoltaic panels ,2011), international conference on renewable energies and power quality (ICREPQ 11) .

[20]. A.Ali Elamin , G.Ahmed Abdalla Mohmmed, M.Hbeeb Ahmed El kanzi , A.Abdalla Ahmed Elfaki ,A.Sulaiman Mohamed Khareif .(2017),Cgange in Electrical parameters Due to partial shading of pv solar cell, American Journal of energy science ,volume 1, page (1-4).

[21]. V. R. Gowariker, N. V. Viswanathan and, J. Shreedhar ,( 2005) ,Polymer Science, New Age International, New [22]. HK. Elminir, AE.Ghitas, RH. Hamid, F. El-Hussainy and MM .Beheary, (2006), Effect of dust on the transparent cover of solar collectors, Energy Convers Manage , Volume 47, page (3192-3203). [23]. AY. Al-Hasan ,(1998), A new correlation for direct beam solar radiation received by photovoltaic panel with sand dust accumulated on its surface. Solar Energy, Volume 63, page (323-333). 